\title{
Environmental Issues in the South China Sea: Legal Obligation
}

\section{and Cooperation Drivers ${ }^{\mathrm{i}}$}

\author{
Nguyen Chu Hoi ${ }^{1}$, Vu Hai Dang ${ }^{2}$ \\ ${ }^{1}$ Former Deputy Administrator, Vietnam's Administration for Seas and Islands; Associate Professor of Marine Science \\ and Governance Policy, Vietnam National University. \\ ${ }^{2}$ Doctor in Law, Researcher at the East Sea Institute and Lecturer at the Faculty of International Law, Diplomatic \\ Academy of Viet Nam.
}

Received: March 18, 2018 Accepted: April 24, 2018 Online Published: May 7, 2018

doi:10.11114/ijlpa.v1i1.3260

URL: https://doi.org/10.11114/ijlpa.v1i1.3260

\begin{abstract}
Recently, we have been witnessing a critical level of a the degradation of the marine environment and depletion of fish stocks in the South China Sea. This has many adverse consequences on the politics, economics of the countries in the region as well as on the socio-economic life of the coastal population. One of the activities that has been causing serious damage to the marine environment and living resources of the South China Sea is the large-scale land reclamation and artificial island construction undertaken by China in the Spratly and Paracel islands recently. These activities have caused severe harm to the precious coral reef environment and thus, violated the obligation to preserve and protect fragile ecosystems and the habitat of depleted, threatened or endangered species under the international law of the sea

The paper explores the impact of China's large-scale land reclamation and artificial island construction activities on the marine biodiversity of the South China Sea, explains what the legal obligation under the international law of States to protect and preserve the marine environment is and suggests a number of options in order to bring a halt to such activities and restore the damaged marine ecosystem. The paper puts particular emphasis on the cooperation drivers torwards a healthy, prosperous and peaceful South China Sea, which also contribute to the management and possibly, resolution of the current disputes in this region.
\end{abstract}

Keywords: marine environmental issues, legal obligation, cooperation drivers, large-scale reclamation, artificial islands, blue solutions and fragile ecosystems.

\section{Introduction}

The South China Sea - SCS (also known in Vietnamese as 'Bien Dong'-East Sea) is a large marginal sea, encompassing an area of around 3,500,000 square kilometers (1,400,000 square miles) stretching from the Singapore and Malacca Straits to the Strait of Taiwan. The sea is rich in marine living resources and has an unknown amount of oil and gas (most of which are difficult to be developed and thus far relatively unexploited). According to the statistics, about one third of the world's commerce and half of the world's oil pass through the SCS every year (MacDonwell, 2011).

The SCS is one of the most important large marine ecosystems (LME) in the world which is rich in marine living resources, providing an important source of the livelihood for communities living in its coastal and island area. The United Nation Environmental Programme (UNEP) affirmed that the SCS countries produce 1/10 of the total marine fish catch of the world and at the year 2030, China will consume by itself $40 \%$ of the total global fish production (Borton, 2016).

The richness of the marine living resources of the SCS depends very much upon the biodiversity and heath of its coastal and marine ecosytems, as well as its marine environmental, especially its offshore coral islands fomed by different natural features (coral islands/islets, atoll and submerged reefs). The offshore coral reefs of the SCS are mostly located beyond $50 \mathrm{~km}$ from any major land masses. They include Pratas and Scarborough atolls, and numerous reefs within the Spratly and Paracel island groups. There are also other offshore coral reefs but most of them do not have more than 5-10 $\mathrm{m}$ in area, and many are poorly known reefs scattered across the numerous banks and continental shelf areas. Many of these features are subject to overlapping sovereignty claims by two or more regional coastal States/Territory, including China, Taiwan, the Philippines, Brunei, Malaysia and Viet Nam. 
The offshore reefs and atolls are "ocean oases" because they serve as potential refugia for corals and many coral fishes, an important component of the marine food-web,... The ecological significance of each reef in particular and the offshore reef system as a whole is very documented (Juinion-Meñez \& Gomez, 2016). According to Danwei Huang et al, 2014, despite containing less than $17 \%$ of the reef area as compared to the Coral Triangle (its core zone is the Philippines and Indonesia), the central waters of the SCS hosts 517 known species of reef-building corals (Huang, Licuanan, Hoeksema, Chen, Ang, Huang, Lane, Vo, Waheed, Affendi, Yeemin, \& Chou, 2014) thus creating a 'Coral Sub-Triangle' in this sea (see Fig. 1). The center of the Coral Sub-Triangle in the SCS is the Spratly's coral reefs which serve as habitats, nursery and feeding areas for many marine fish species not only in the Spratly's waters, but also in the entire SCS and even beyond it thanks to the seasonal marine circulation (Nguyen Chu Hoi \& Vu Hai Dang, 2015).

In fact, the SCS region has been facing with the challenge due to environmental degradation and fish stocks depletion at a critical level. This environmental security issue would become a human security issue due to its negative impacts to the politics, economic, and social landscape of the region. From that point of view, the consequences of the recent large-scale land reclamation and construction of artificial islands undertaken by China on a number of natural features in the Spratly and Paracel Islands are particularly serious. These activities not only caused severe harm to the coral reef environment of the SCS but also violated the international legal obligation to preserve and protect fragile ecosystems (coral, seagrass and other shallow waters ecosystems) and the habitat of depleted, threatened or endangered species.

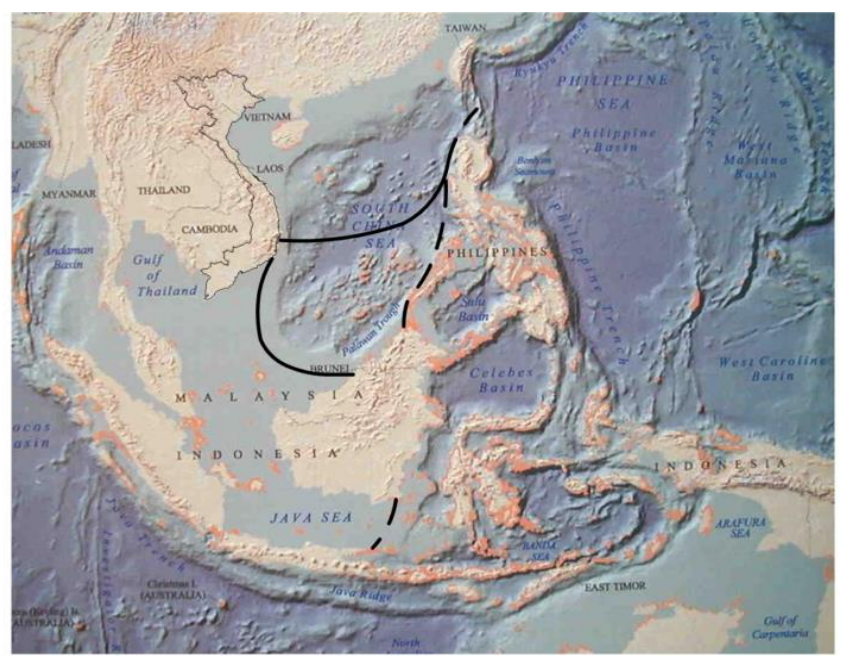

Figure 1. The 'Coral Sub-Triangle' in the SCS

(Vo Si Tuan, 2014)

The marine environmental issues in the SCS, including and especially those arising from the recent large-scale land reclamation and construction of artificial islands have to be addressed based on the clarification of the legal obligation of relevant stakeholders, as well as through the proposed cooperative initiatives, focusing on blue ocean solutions and the enforcement of international law, in particular UNLCOS. The suggested solutions could contribute to a healthy, prosperous and peaceful SCS, as well as to the management and resolution of the current SCS dispute.

\section{Consequences of the Recent Large-Scale Land Reclamation and Construction of Artificial Islands to the Marine Environment of the South China Sea}

\subsection{Consequences to Offshore Reef Systems}

The geological structure and the floor morphology of the SCS is complex with wide continental shelves, steep slopes and a 'deep-sea basin' covered over 55\% total area of the sea-floor which is considered by Morton and Blackmore, 2001 as an abyssal plain from which clusters and chains of seamounts arise (see Fig.2). This marine region has hundreds of coral islands/islets, submerged reefs (shoal, rock and low-tide elevation). 


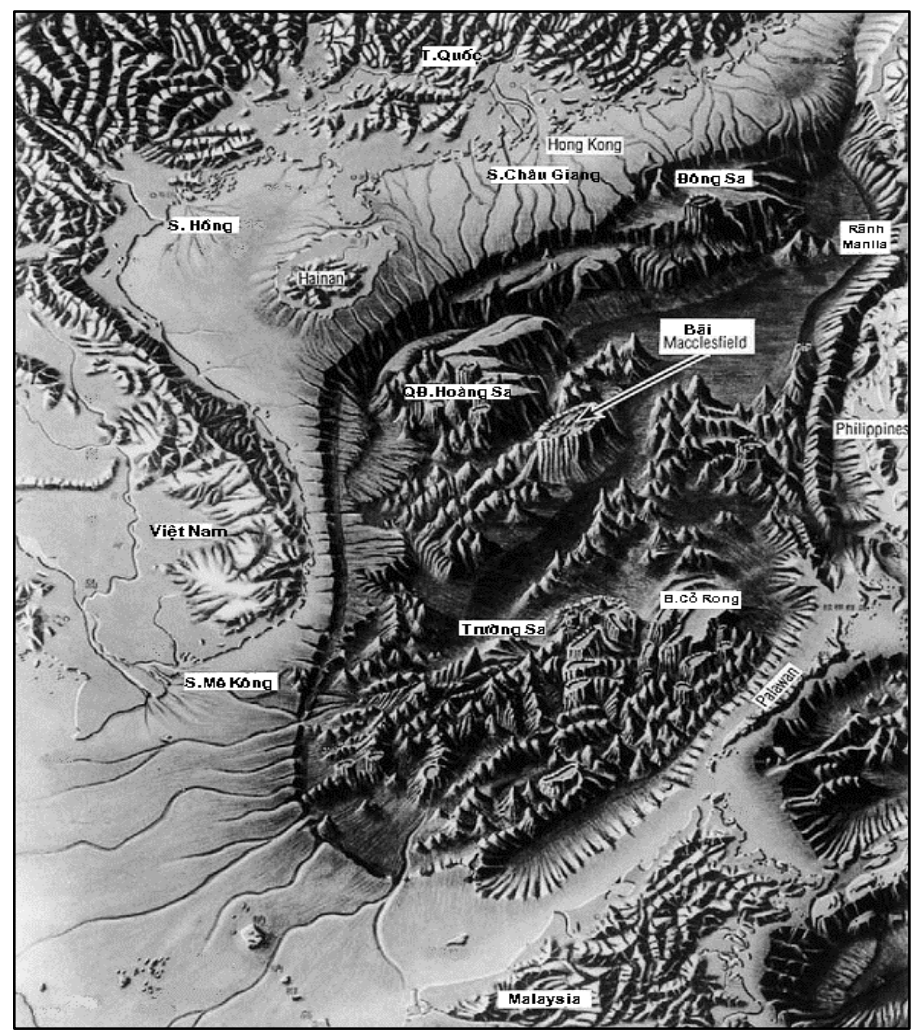

Figure 2. Schema of the sea-floor morphology of the SCS

(Morton \& Blackmore, 2001)

A number of studies indicate that the offshore reefs in the SCS are not only important to the biodiversity of this region itself, but also to the adjacent Coral Triangle, considered the center of global marine diversity (Hoeksema, 2007). Consequently, the degradation of these offshore reefs may have caused detrimental effects on the reef health throughout the SCS and part of the Coral Triangle region. Even though direct field studies on the status of the offshore reef systems in the SCS are limited and not updated, the remote sensing image and GIS monitoring results have provided valuable information to better understand and manage these reefs. These are information and data on the depth, morphological changes of atolls,.... Based on these information, marine scientists estimate the minimum area of damaged reefs due to large-scale reclamation artificial island building and poaching of giant clam shells (McManus, 2016).

The activities of building artificial island in the Spratlys started since December 2013, when China has reclaimed nearly $14 \mathrm{~km}^{2}$ of reef in the SCS. Satellite images have shown the progress of China's activities, which have drastically outstripped the pace and extent of other countries' efforts. For example, Subi Reef alone was object to an expansion of $74 \%$ of its original size in only two months, with filling occurring at an average rate of at least $32,000 \mathrm{~m}^{2}$ per day (Lee, 2015). McManus, 2016, stated that "Escalating tensions have led to widespread structural reinforcement of military outposts on many reefs via dredging and filling. Satellite images indicated at least $160 \mathrm{~km}^{2}$ of coral reef damage, including $17 \mathrm{~km}^{2}$ in essentially permanent damage from filling and channel/harbor dredging, and $143 \mathrm{~km}^{2}$ of decadal-scale damage from dredging for building materials and giant clam harvesting (see Table 1-below-edition added)." According to McManus, with the total filling area covering $14.9 \mathrm{~km}^{2}$ of reef ecosystem, and another $2.5 \mathrm{~km}^{2}$ of channel and harbor dredging, it is apparent that the world had lost at least $17 \mathrm{~km}^{2}$ of its more highly diverse and fishery productive coral reefs, essentially permanently. While not as permanent and severe, the additional clam harvesting and shallow dredging of reef flats and lagoons for building materials had seriously disrupted $143 \mathrm{~km}^{2}$ of important ecosystems within these valuable reefs, with impacts that may last for decades. China is responsible for approximately 99\% of the overall damage from these activities among offshore coral reefs in the SCS (McManus, 2016). 
Table 1. Areas (in $\mathrm{km}^{2}$ ) of damage to shallow coral reefs in the SCS (McManus, 2016) ${ }^{\mathrm{ii}}$

\begin{tabular}{|c|c|c|c|c|c|c|}
\hline Greater Spratly islands (GSI) & \multicolumn{3}{|c|}{ Dredging Channel Shallow } & \multirow{2}{*}{$\begin{array}{c}\text { Giant } \\
\text { Clamming } \\
68.75\end{array}$} & \multirow{2}{*}{$\begin{array}{l}\text { Row } \\
\text { Sums } \\
122.66\end{array}$} & \multirow{2}{*}{ 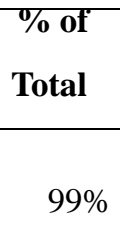 } \\
\hline People's Republic of China & 13.23 & 1.38 & 39.30 & & & \\
\hline Vietnam & 0.27 & 0.21 & 0.26 & --- & 0.74 & $<1 \%$ \\
\hline Malaysia & 0.37 & 0.05 & -- & --- & 0.42 & $<1 \%$ \\
\hline Taiwan & 0.04 & 0.04 & --- & --- & 0.08 & $<1 \%$ \\
\hline Philippines & 0.06 & -- & --- & --- & 0.06 & $<1 \%$ \\
\hline Total, GSI & 13.91 & 1.68 & 39.56 & 68.75 & 123.95 & \\
\hline Percent of GSI Damage by PRC & $95 \%$ & $82 \%$ & $>99 \%$ & $100 \%$ & $99 \%$ & \\
\hline \multicolumn{7}{|l|}{ Paracel Islands } \\
\hline People's Republic of China (PRC) & 1.01 & 0.86 & 0.00 & 35.02 & 36.89 & \\
\hline Total, South China Sea & 14.92 & 2.54 & 39.56 & 103.77 & 160.84 & \\
\hline Percent of All Damage by PRC & $95 \%$ & $\mathbf{8 8 \%}$ & $>99 \%$ & $100 \%$ & $99 \%$ & \\
\hline
\end{tabular}

In the process of building the artificial islands and their infrastructure for military bases such as ports, hangars and airstrips, the dredged coral sands, fragments and sediments have been sucked up from the sea floor then pumped over the atolls which are permanently destroyed, together with all the valuable ecosystem goods and services they provide. Surrounding reefs are also likely to have been affected, potentially suffering from exposure to large clouds of suspended sediment (Mora et al. 2016). For instance, turbidity plumes from island-building activities on Mischief, Subi and Fiery Cross Reefs can extend over 4,300 km² (Barnes \& Hu, 2016). Massive dredging of sand and corals, dumping sand on top of submerged and partially submerged reefs, and constructing giant concrete seawalls to protect manmade structures. China is also topping its fully reclaimed islands with helipads, airstrips, military support buildings, solar installations, wind turbines, concrete plants, and radar towers, while also adding on harbors, piers, and desalination pumps. In other words, China is burying reefs under sand and concrete. This would be troubling in any context, but it's especially worrisome in the Spratly Islands' (Loftus-Farren, 2015).

The cause of rapid destruction for the offshore coral reefs, which amounts to nothing less than a widening environmental crime scene, is the land reclamation activities conducted by the China as it attempts to turn rocks into islands and bolster its expansive claims. The result of this reclamation work is less biodiversity and fewer fish left to feed the growing populations of claimant nations (Borton, 2016). The damaged shallow reef in the Spratly area represents approximately $10 \%$ of the total shallow reef area, and roughly $3 \%$ of the total reef area at depths visible to areal and satellite images and about $8 \%$ of the $481 \mathrm{~km}^{2}$ total reef area estimated for the Paracels. The loss of reefs in the two reef groups (Paracel and Spratly) may have a significant impact on both reef and migratory pelagic fishes dependent on the ecosystem services (e.g., enhanced primary productivity) of these offshore reefs (Juinion-Meñez \& Gomez, 2016).

The recent unprecedented massive reef dredging and filling undertaken by China to build artificial islands has account for $95 \%$ of the reclaimed reefs. Considering the estimated value of coral reef ecosystem services (i.e. provisioning, regulating, habitat and cultural) at USD 350,000 per hectare (De Groot, Brander, Der Ploega, Costanza, Bernard, Braat, Christie, Crossmang, Ghermandi, Hussain, Kumar, Mc Vittie, Portela, Rodriguez, Brink, Beukering, 2012), the losses due to reclamation and artificial island building may be over USD 4.0B annually. Alterations of ecosystems break food web links, affect primary and secondary productivity. Total destruction of these critical reef areas has potentially broader scale and long-term impacts leading to species and genetic diversity loss both in terms of direct reef fisheries and migratory oceanic fish harvests (Juinion-Meñez \& Gomez, 2016).

\subsection{Consequences to Marine Biodiversity and Fisheries}

The SCS is rich in marine living resources with an estimated statistic of 3.000 fish species, accounting for $12 \%$ of total fish catch production of the world. There are about 1.72 million fishing boats and vessels in the SCS region. However, the fish stock of the SCS has been severely damaged: according to a 2008's estimation, about $25 \%$ to $50 \%$ of fish 
species with commercial value of the SCS has been overexploited (Nguyen Ngoc Truong, 2016). The FAO's map of marine fish reserves in the SCS showed that the fishing grounds in Northern SCS (near China), Tonkin Gulf (near Vietnam), Thailand Gulf and Paracel islands have been severely overexploited, to a nearly depleted level (see Fig.3).

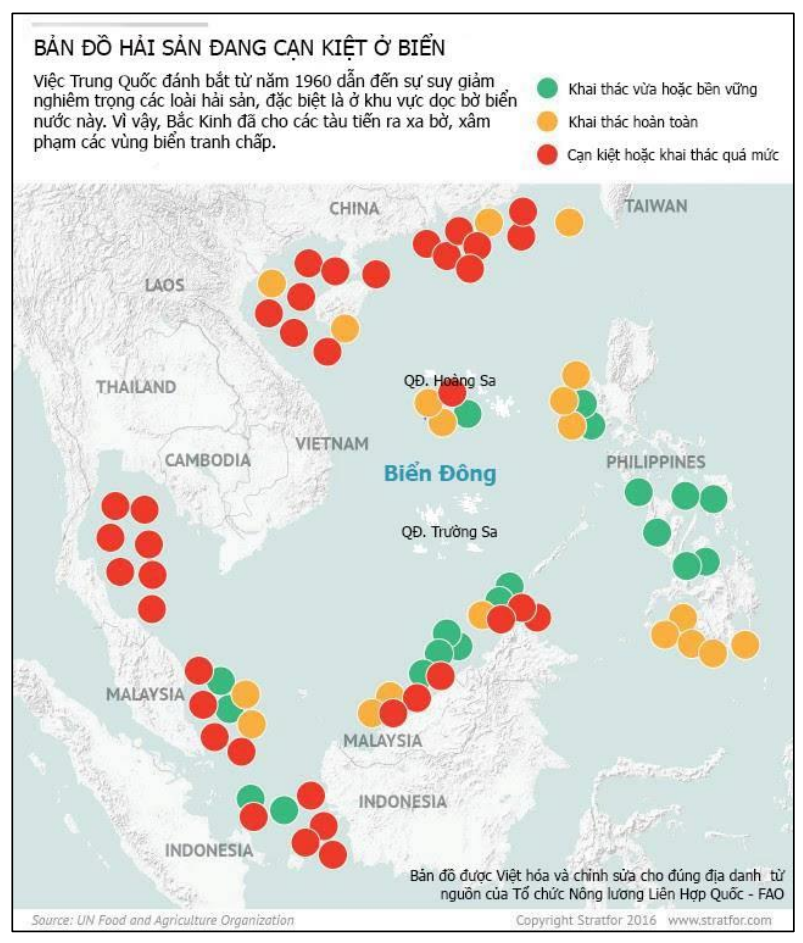

Figure 3. The map of the exhausted fishing in the SCS

(FAO, modified from Vietnamese version) ${ }^{\mathrm{iii}}$

Main reasons for the depletion of the fish stock in the SCS are: (i) The activities of building islands and burying offshore reef systems by China, which have caused permanent damages to the marine habitat in the SCS; (ii) Unprecedented fishing efforts undertaken by large-scale Chinese fishing fleets; (iii) Subsidies provided by regional governments to their fishermen, for example China provided fuel and military support to long-distance fishing vessels fishing or Viet Nam provided funding to national fishermen to build new and improved ones; (iv) The national policies of encouraging fishermen to enhance offshore fishing to avoid depleting coastal resources, etc.

According to McManus, 2016: "This combination of fisheries effort enhancement and subsidy are driving the regional fisheries into a much worse state than the poor state that market forces alone would have induced". Regional states such as China, Vietnam, the Philippines have encouraged their fishermen to enhance their offshore fishing as an effort to reinforce national claims of sovereignty and jurisdiction in the SCS. For instance, China has equipped approximately 50,000 marine fishing vessels fishing in the SCS with positioning and communications devices to maintain close contact with naval vessels in case needed. Chinese fishing vessels are supported by the logistic vessel which are of 3.000-4000 tons, having the capacity to process the fishes catched right away at sea (McManus, 2016).

In 2014, Asian countries export about $1 / 3$ of the world total fishes, among which, China alone export $12,5 \%$ of the world fishes. This value has increased $200 \%$ in comparison with 7 years earlier. In 2013, the fisheries sector contributed about 289 billion USD to China's economy. The marine economics of the China has created 14.5 million employments. Incomes of fishers are also 50\% higher than farmers. Because of the importance of the fisheries sector, the Chinese government has subsidized its fisheries sector every year with a total value of about 4 billion USD since 2010 (McManus, 2016). There is equally the problem of illegal fishing at seas. The above-mentioned activities certainly caused adverse impacts to the marine biodiversity, living resources, environment and fisheries sector of the regional states, making the tension in the SCS grow even higher.

The above-mentioned consequences from the land reclamation and artificial island building activities undertaken by China in the Spratly and Paracel Islands have exacerbated the depletion of the marine fish stocks in the SCS due to overfishing in the region. These reclamation and artificial island building activities severely damaged the health and productivity of the SCS, a large marine ecosystem (LME) shared by half dozens of countries. Thus, China's accelerated 
land reclamation and artificial island building activities is causing a major environmental catastrophe, endangering fishing stocks, threatening marine biodiversity; and posing long-term threats to some of the world's most spectacular coral reefs system (Gomez, 2015).

China's disregard for the environment has not only provoked dramatic changes in the natural structures and functions of shoals, coral reefs and atolls, but also broke the ecological connectivity between the reef systems and the SCS. This has negatively impacts on the supply of the nutrients and spillover effects of fish breeding in the SCS. Moreover, the widespread destructive fishing practice in the SCS has also caused degradation to the marine ecosystems and reduction in great numbers of many important endangered species, such as sea turtles, shark and giant clams. As a result, the fish stock in Spratly's marine waters and the western part of the SCS has been now reduced by $16 \%$ compared to pre- 2010 (Nguyen Quang Hung \& Vu Viet Ha, 2015).

In the SCS, the ecological connectivity between offshore reef groups with the ones locating in and beyond the marine region has been "cut". This has adverse impact on the resource base to develop sustainably the marine fisheries sector in short-term and in long-term, thus provoking the reduction of "marine natural asset" for blue growth for the regional coastal/island states. Consequently, millions of fishermen from Vietnam, Philippines, Malaysia, Indonesia,... but also from China herself will have to bear these negative consequences.

Marine scientists from the Philippines showed that "perhaps significantly more damaging, though less publicized than the reclamation is the widespread poaching of giant clams in the SCS. Exploitation of the giant clam, mainly but not limited to the species Tridacna gigas, has grown in recent years. Its meat is historically popular as an aphrodisiac and delicacy in China and other countries, and its shell has become the unfortunate substitute for the fiercely banned elephant ivory. A largely domestic industry has grown and become socio-culturally enmeshed in Tanmen town in the southern Chinese province of Hainan". Presently, the town harbors over 460 shops selling giant clam carvings, providing livelihood for over 100,000 residents (Larson, 2016). Though harvesting giant clams has technically been prohibited in the area, shop owners continue to receive a steady, unhampered supply and local boats have even been encouraged to expand their range in the SCS (Larson, 2016).

Tridacna gigas is vulnerable and locally extinct in some areas (IUCN, 2016). It is a long-lived species which take a lot of time to reach sexual maturity and to reproduce. "The distribution of T. gigas is restricted to East Asia and the Pacific, the SCS the westernmost portion of its range (reviewed in Bin Othman et al., 2010 \& Rosewater, 1965). The industrial-level extraction of giant clams from the Spratlys, as well as from the Scarborough Shoal, translates to a great loss of productivity in the coral reef ecosystems of the SCS and even those farther afield" (Mc Manus, 2016).

Giant clams are harvested by disturbing the substrate using the boat propellers to remove the animals from the substratum (Lee, 2015). Until recently, the prevalence and scale of this reef mining activity was not known. However, recent analyses of satellite imagery have shown that nearly 69 square kilometers of coral reef in the SCS bear arc-shaped scarring from these propellers. Nearly all giant clams in the area have been removed leaving the plundered reef, barren and irreversibly destroyed (Mc Manus, 2016).

To prevent the extirpation of all giant clam species in the SCS, there is a need for a complete halt of giant clam shell gathering. No doubt, much of the gathering of live clams had been done prior to the last few years. However, the demand for shells in Hainan grew rapidly only in the recent past. Given that the need for shells remains, gatherers will not make a distinction between live and previously dead clams. Hence, all gathering must cease, if any living animals are to be spared. This is in accordance with the spirit of the Convention on the International Trade of Endangered Species of Wild Fauna and Flora, which makes no distinction between live or dead organisms, because in the trade of relevant materials, one often cannot tell whether the source of the artifact was dead or alive before collection (Huang et al, 2014). In addition to this, the number of reefs and associated fish species in the disputed marine waters in the SCS have been reduced from 460 down to 261 and the list of dangerous species has been added with the blue turtle, giant clam and tortoise (Mc Manus, 2016).

\section{Implications of the South China Sea Award to the Protection and Preservation of the Marine Environment of the South China Sea}

The award by the arbitral tribunal in the Philippine vs China case in 2016 (South China Sea Award) provides useful precision on how to carry out various obligations to protect and preserve the marine environment in the SCS under the United Nations Convention on the Law of the Sea, 1982 by stipulating which the activities constitute violations of these obligations. This part of the paper explains the obligations to protect and preserve the marine environment is under the United Nations Convention on the Law of the Sea, 1982 referred to by the arbitral tribunal and the activities considered their violations. 


\subsection{The Obligations to Protect and Preserve the Marine Environment under UNCLOS, 1982 Referred to by the Arbitral Tribunal}

The United Nations Convention on the Law of the Sea or UNCLOS signed in 1982 at Montenegro Bay, Jamaica is considered "a Constitution for the Oceans" (Koh, 1982). The Convention comprises more than 300 articles providing for the most basic rights and duties of States relating to the seas and oceans, regulating practically all human activities at sea. As such, it contains many provisions relating to the obligations of States to protect and preserve the marine environment. Five of these provisions are referred to by the arbitral tribunal, namely the articles: 123, 192, 194, 197 and 206. A detailed description of these articles follows:

Article 123 of UNCLOS calls for the cooperation of States bordering enclosed or semi-enclosed seas ${ }^{\mathrm{iv}}$ (UNCLOS, 1982). With regards to the protection and preservation of the marine environment, it states that States shall endeavour, directly or through an appropriate regional organization, coordinate the implementation of their rights and duties with respect to the protection and preservation of the marine environment.

Article 192 of UNCLOS recognizes a general obligation of all States to protect and preserve the marine environment (UNCLOS, 1982). To undertake this obligation, article 194 stipulates that States shall take all measures to prevent, reduce, and control pollution from any source and to ensure that activities under their jurisdiction or control are so conducted as not to cause damage by pollution to other States and their environment. These measures include those designed to minimize the pollution from practically all installations and devices operating in the marine environment and those necessary to protect the to protect and preserve rare or fragile ecosystems as well as the habitat of depleted, threatened or endangered species and other forms of marine life (UNCLOS, 1982).

Article 197 imposes an obligation of cooperation for the protection and preservation of the marine environment. It requires States to cooperate on a global basis and, as appropriate, on a regional basis, directly or through competent international organizations, in formulating and elaborating international rules, standards and recommended practices and procedures consistent with this Convention, for the protection and preservation of the marine environment (UNCLOS, 1982).

Article 206 concerns with the obligation of undertaking environmental impact assessment before implementing risky activities to the marine environment. It provides that when States have reasonable grounds to believe that planned activities under their jurisdiction or control may cause substantial pollution of or significant and harmful changes to the marine environment, they shall assess the potential effects of such activities on the marine environment and shall communicate results of such assessments at appropriate intervals to the competent international organizations, which should make them available to all States (UNCLOS, 1982).

Now that the content of these obligations is determined, it is interesting to see which activities are considered by the arbitral tribunal their violations.

\subsection{Activities Considered to be Violations of the Obligations to Protect and Preserve the Marine Environment}

The arbitral tribunal stated that two types of activities by China are in the violation of the obligations to protect and preserve the marine environment under UNCLOS, 1982 as listed earlier, namely the toleration, protection and failure to prevent Chinese fishing vessels engaging in harmful harvesting activities of endangered species (i) and China's land reclamation and artificial island building activities (ii).

\subsubsection{Toleration, Protection and Failure to Prevent Harmful Harvesting Activities of Endangered Species}

First, the arbitral tribunal recognizes that Chinese fishing vessels have been involved in harvesting of threatened or endangered species on various occasions based on the evidences submitted by the Philippines:

(a) In January and March 1998, Chinese fishermen were found in possession of corals and marine turtles.

(b) In April 2000, Chinese fishing vessels were found with four tons of corals on board.

(c) In January 2001, Chinese fishing vessels were found with endangered sea turtles, sharks, and corals.

(d) Tons of corals as well as clams were confiscated from Chinese fishing vessels in February, March and September of 2002.

(e) In October 2004, Chinese fishing vessels loaded and photographed with giant clams were intercepted by the Philippine Navy.

(f) In December 2005, four Chinese fishing vessels were found and photographed in possession of "assorted corals and live clamshells weighing about 16 tons".

(g) In April 2006, Chinese fishing vessels were found and photographed with corals. 
(h) On 10 April 2012, large amounts of corals and giant claims were found and photographed on board Chinese fishing vessels that were later joined by Chinese Government vessels.

(i) On 23 and 26 April 2012, at least two Chinese fishing vessels, operating under the protection of CMS vessels were observed to have giant clams inside the cargo hold (South China Sea Award).

As the consequences of those activities, the arbitral tribunal considers the harvesting of sea turtles, species threatened with extinction, to constitute a harm to the marine environment. It further stated the harvesting of corals and giant clams at a large scale as did Chinese fishermen has a harmful impact on the fragile marine environment. Thus, the arbitral tribunal considers the failure to prevent these practices by China is a breach of the articles 192 and 194 (5) of UNCLOS (South China Sea Award). More interestingly, the simple adoption of appropriate rules to prohibit harmful practices is not enough to be considered in compliance with the duty of States with regards to endangered species. They must also take steps to enforce these rules against fishermen engaging in the poaching of these species (South China Sea Award).

The arbitral tribunal also condemns the use of cyanide and dynamite, which are considered by independent experts "highly destructive methods" and "the most highly destructive of all fishing methods" (South China Sea Award). Even though the arbitral tribunal did not make any conclusion on the failure of China to prevent these practices due to the lack of evidence, it considers that the use of cyanide and dynamite is a violation of articles 192, 194(2) and 194(5) of the UNCLOS (South China Sea Award).

\subsubsection{Land Reclamation and Artificial Island Building Activities}

The arbitral tribunal agreed with the appointed independent experts that despite the fact that the early construction and land reclamation works on these islands have had some negative impacts its coral reefs, the most serious destruction come from China's recent construction (South China Sea Award). According the report from Dr. Sebastian Ferse, the appointed independent expert on coral reefs:

China's recent construction activities have and will cause environmental harm to coral reefs at Cuarteron Reef, Fiery Cross Reef, Gaven Reef, Johnson Reef, Hughes Reef, Mischief Reef, and Subi Reef; beyond the pre-existing damage to reefs that resulted from destructive fishing and the collection of corals and clams, storm damage, Crown-of-Thorns starfish, and the human presence on small garrisons on the reefs (South China Sea Award).

Worse still, Dr. Ferse opines that some activities will have permanent or long-lasting effects on a large part of the reefs, such as reclaiming reef flats, excavating channels, and sediment resuspension in lagoons (South China Sea Award).

Thus, the arbitral tribunal stipulates that China's artificial island-building activities have violated the obligation under article 192 to protect and preserve the marine environment, the obligation under article 194(1) to ensure that activities under their control do not to cause damage by pollution to the environment, and the obligation under article 194(5) to take measures necessary to protect and preserve rare or fragile ecosystems as well as the habitat of depleted, threatened or endangered species and other forms of marine life (South China Sea Award).

The arbitral tribunal further states that by conducting the land reclamation and artificial island building activities, China has failed to respect the obligations to cooperate for protection and preservation of the marine environment. First, China did no respect the obligation to cooperate on a regional basis to formulate standards and practices for the protection and preservation of the marine environment as required by article 197. Second, China did not respect the one to endeavour to coordinate the implementation of their rights and duties with respect to the protection and preservation of the marine environment in a semi-enclosed sea as required by article 123 (South China Sea Award).

It is interesting that even though the State Oceanic Administration (SOA), the agency in charge of ocean governance in China, released two documents to assess the impact of these land reclamation and artificial island building activities,(SOA, 2016) the arbitral tribunal still considers that China has not fulfilled its obligation to undertake an environmental impact assessment and to communicate its results under article 206 of UNCLOS. According to the arbitral tribunal, these two documents do not meet the requirements of an environmental impact assessment both under article 206 and China's own law. Besides, China also failed to communicate these documents to any international forum or body as required (South China Sea Award). It should be noted that content of these two documents, which claim that China's land reclamation and artificial island building activities "do not damage the environment on the reefs" was strongly disagreed by the arbitral tribunal based on "the compelling evidence, expert reports, and critical assessment of Chinese claims" (South China Sea Award).

\section{Cooperation Drivers for a Blue SCS}

\subsection{The Concept}

The above discussions has reaffirmed that we were witnessing a downgrade of the environmental security and depletion of fish stocks at a critical level in the SCS which have adverse consequences on the politics, economics of the countries 
in the region as well as on the socio-economic life of the coastal population. In the past, a series of the initiatives and solutions to manage the tensions and conflicts in the SCS have been proposed by different scholars and policy-makers both inside and outside the region. The practice also suggests that relevant parties (stakeholders) in the SCS should enhance its role by seating together with China to solve the maritime dispute in general and the environmental issues in particular in the SCS with a "lofty spirit". This could start first by a discussion about strategic confidence building, including effective implementation of the articles 5 and 6 of the DOC (DOC, 2012), and an early conclusion of the COC.

The tribunal had considered the effect on the marine environment of China's recent large-scale land reclamation and construction of artificial islands in seven features in the Spratly Islands and found that China had caused severe harm to the coral reef environment and violated its obligation to preserve and protect fragile ecosystems and the habitat of depleted, threatened, or endangered species. The tribunal also found that Chinese authorities were aware that Chinese fishermen have harvested endangered sea turtles, coral, and giant clams on a substantial scale in the SCS (using methods that inflict severe damage on the coral reef environment) and had not fulfilled their obligations to stop such activities (PCA, 2016).

To deal with these environmental issues, China must become a model in implementing the international law for other countries to follow. Meanwhile, regional countries have to reach a unified solution on a mechanism to monitor the environment and educate their fishers to protect the marine environment and fishery resources of the SCS. There has been appeals towards regional countries and international environmental organizations to take necessary actions together to protect the SCS environment in order to achieve 'a blue SCS - healthy sea, prosperious sea and peaceful sea' (Nguyen Chu Hoi, 2016) which is also this paper's main message.

It is well understood that "deterioration of ecosystem health and climate change will further exacerbate the precarious situation of many coastal populations globally. It is imperative that further damages to these fragile ecosystems be forestalled. Much needs to be done and there are many proposals to move forward in various spheres of interest. Among the immediate concerns are overfishing (Teh et al, 2016) and destruction of critical reef ecosystems. It is evident, based on well-established scientific knowledge and international standards on dredging in coral reefs, that artificial island building on offshore reefs, and giant clam mining have resulted in irreversible damages and large-scale degradation and clearly compromise the inherent rights of many coastal communities and future generations under UNCLOS as recognized by the ruling of the Permanent Court of Arbitration at The Hague" (Huang et al, 2014).

The common goal of securing the future for the next generations rests upon the maintenance of highly connected natural and socio-economic regional linkages in the SCS (Juinio-Meñez 2015). Protection of the natural connectivity and mitigation of human-induced threats to ecosystem health are important first steps in forestalling losses and irreversible ecological damage in the SCS. The science and practice is common among littoral states bordering the SCS. Building the regional expertise on coral reefs and experience in marine protected areas (MPAs) and integrated coastal resources management (ICM) are strategic in scaling up conservation and management efforts to safeguard long-term transboundary socio-economic and ecological stakes (Huang et al, 2014).

Recent tendency focuses more on science-based strategic solutions to link the scientific to political solutions for the strategic confidence building. According to Borton: "The sovereignty of each state is severely compromised if it cannot guarantee the integrity of its own marine resources and environment. The marriage of policy and science, or rather the implementation of science diplomacy, may help claimants to safely navigate through these perilous contested waters. More specific regional threats derive from transboundary transgressions in the region, and as result, nations have witnessed an increasing level of violence. Science has been adopted as a diplomatic tool for peace-building for several decades by many countries, including the United States and recently, the such initiative has been held in the Republic of Korea by the Korea Institute of Ocean Science and Technology (KIOST) (Borton, 2016).

Our concept is that the science diplomacy in the SCS have to: (i) maintain and improve the existing initiatives and solutions, then (ii) also to promote new initiatives and solutions. The emphasis is put on the blue initiatives and solutions and a step by step approach to implement effectively the cooperative drivers.

\subsection{The Proposed Blue Solutions for Maintaining and Improving the Existing National and Regional Initiatives}

In the SCS's offshore reefs systems, albeit relatively small in area compared to the nearshore ones, play a critical role in maintaining the biophysical transboundary connectivity essential in maintaining the benefits derived from biodiversity goods and services (Huang et al, 2014). Now there has been already enough scientific evidences to support the establishment of protected areas to protect these offshore reef systems in the SCS which are beneficial not only for coastal countries this but also to other states beyond this marine region (such as those bordering the Coral Triangle). According to the IUCN, the Peace Park is a special category of transboundary protected areas which has the purpose to not only protect natural and cultural values but also to promote peace and cooperation (Vu Hai Dang, 2015). 
Establishing a Peace Park in Spratly. Years ago, before China's extensive land reclamation and artificial island building activities began (around 1989, 1992), McManus proposed the establishment of a Spratly Island Peace Park, in order to protect the high biodiversity and ecological value of the coral islands and to reduce the growing tension in the region. Recently, he has enlarged his original initiative by suggesting the establishment of a Greater Spratly Islands Peace Park, which would also include Scarborough Reef. Besides these areas, another important area to be considered for as the establishment of a peace park is the Paracel Islands (McManus, 2016). This will not only provide strong support to help stabilizing the fish stocks across the SCS, but also promoting tourism and regional political stability.

He also suggested that the administration of such as Peace Park could be handled by an independent contracted agency, under the supervision of a panel consisting of claimant nations and with an advisory panel made up of thematic experts of global stature. For the Paracel Peace Park, "given the strongly entrenched nature of the PRC within this island group, it may be difficult to establish such a Peace Park until such time as Vietnam challenges the PRC for sovereignty rights via international arbitration. Should the PRC's position as the legal administrators of the Paracels be thus challenged, then perhaps a Paracels Peace Park could be considered as an alternative to the unlikely option of the PRC abandoning the island group" (McManus, 2016). The idea and proposal of John McManus have been received the stronggly support from a number of scholars and managers in the world. For example, according to Vu Hai Dang, 2015, establishing a Marine Peace Park in the Spratlys is an option for implementing the DOC in the SCS (Vu Hai Dang, 2015).

Linking available networks of national marine protected areas (MPA) through a coordinated application of the national laws relating to MPAs and MPAs network of China, the Philippines and Viet Nam. This approach suggests that each above-mentioned State could establish a separate marine peace park in the Spratlys in the area under their claim under their national law. Since the rules relating to the establishment and management of MPAs under Chinese, Philippine and Vietnamese laws are quite harmonized and compatible, the same measures would be adopted for the protection of this area. For the enforcement of these measures, relevant States could use a flag State jurisdiction: they would only enforce them to vessels flying their own flags and those flying flags of third-party countries (Vu Hai Dang, 2015).

The MPAs have been one of the most viable and politically accepted approaches to marine conservation (e.g. historical development reviewed in Wells et al, 2016) within a broader and integrated management regime. MPA initiatives directly bear on improving resilience of vulnerable and critical ecosystems such as the SCS offshore reefs. Furthermore, there is good evidence that the protection of critical habitats in nearshore reefs help improve fisheries through spillover effects.

Considering the critical role of offshore reefs and atolls as areas of enhanced primary productivity and its critical role as a source of larvae for reefs within the SCS and the Coral Triangle, regional multidisciplinary research to generate important data and information to guide the development of MPA networks consistent with integrated coastal management is critical to enhance regional cooperation. MPA networks have been established to expand the MPA system in the Coral Triangle countries (Huang et al., 2014) and similar efforts are also being undertaken by other littoral states in the SCS. Nguyen Chu Hoi and Vu Hai Dang, 2015 proposed the formulation of a framework for the establishment of a regional MPA network in the SCS (Nguyen Chu Hoi \& Vu Hai Dang, 2015). Building on existing experience on MPAs in the region, scaling up through MPA networks may be a step forward towards the development of a transboundary Peace Park in the SCS as proposed by McManus.

The continuation to implement the GEF/UNEP Project "Implementing the Strategic Action Programme for the South China Sea" (to which participating countries are Cambodia, China, Indonesia, Philippines, Thailand and Vietnam) is also of a particular importance. The Project focuses on capacity building at the national and local levels; provision of opportunities in exchange of experiences and good practices among countries in the SCS; common guidelines and other tools used by countries in management planning and practices, and for standardisation in regional synthesis and comparison; provision of sound scientific information for management; and encourage the participating governments at all levels in developing policy related to environment management (Vo Si Tuan, 2016). The Executing Institution of this Project for the period Sept. 2016 - 2021 is the Coordinating Body for Sea East Asia (COBSEA).

\subsection{The Potential Mechanisms and Initiatives for the Environmental Cooperation in the SCS}

Recently, many mechanisms and initiatives have been proposed at the SCS, East Asia and Asia-Pacific level for environmental cooperation, through which the cooperation between SCS countries could be strengthened. There is no doubt that it is the responsibility to conserve and protect the rich biological resources in the SCS in accordance with the principle of sustainable development lies on coastal states. This is also consistent with the obligations of states bordering a closed or semi-enclosed seas as stipulated by Art. 123 of UNCLOS. However, the disputes over territorial sovereignty and maritime claims may affect adversely any effective conservation measures (Zou, 2015). Notwithstanding these difficulties, there is openness in the region to continue to pursue joint capability building in marine sciences and technology and marine scientific research building on various cooperative regional programs 
(Huang et al, 2014).

(i) Initiatives under the UNESCO Intergovernmental Oceanographic Commission for the Western Pacific (IOC-WESTPAC), which include:

- The Network of Regional Training and Research Centers on Marine Sciences: it aims to provide opportunities for shared learning, generation of new knowledge, and enhanced collaboration among the next generation of scientists and resource managers in the region (IOC WESTPAC, 2018).

- The Sustainable Initiative for the Marginal Seas of South and East Asian: a recent regional initiative, to catalyse the development of international alliance of physical, ecological and social scientists working together to generate policy and community-relevant knowledge towards sustainability of the marginal seas of South and East Asia (SIMSEA, 2018).

- Emerging Issues Ocean Acidification and Resilience to Changes (IOC/WESTPAC, UNEP): this is a new initiative which intends to help in the management of the important offshore reefs. It could be used as a concrete effort to foster cooperation among countries around the SCS (cited in Huang et al., 2016).

(ii) The initiatives and solutions of area-based governance and management for the SCS

The area-based ocean governance and management is a relatively new approach but it has already been implemented in many countries in the world (for example, the USA, EU, China,...). Recently, by using the ecosystem-based marine spatial planning (MSP) tool, scientists have helped coastal and marine managers in determining functional marine spatial areas to protect the marine environment and preserve marine living resources from negative threats of the human behaviours, shipping, and marine natural hazards, including the fishing boats. They are considered an effective tool to contribute to implementation of a number of relevant international, regional agreements and conventions (such as DOC, CBD, CITES, MARPOL, UNCLOS, etc) which have been signed by the littoral states in the SCS (Nguyen Chu Hoi, 2013).

- Establishing and managing 'Ecologically or Biologically Significant Sea Areas (EBSAs) in areas national and beyond national jurisdiction under the framework of the Convention of Biological Diversity: this has been discussed many times under UNCLOS (CBD Secretariat, 2015). In the SCS, at present, except the Ha Long - Cat Ba EBSA in nearshore limestone island cluster of Vietnam (Nguyen Chu Hoi, 2016), there is no second offshore EBSA established even if its offshore reef systems totally meet the required criteria. The main reason is a lack of political support from the claimant states for the reef islands. Thus, enhancing the political awareness of the littoral states of the SCS is very critical to achieve the above-mentioned objectives.

- Establishing and managing 'Particularly Sensitive Sea Area (PSSAs)' under MARPOL Convention: a Vital international shipping route is cutting across the waters between the Spratly Islands and Paracel islands (in particular areas about $38 \mathrm{~km}$ to Con Dao islands of Vietnam). Approximately 5.3 trillion USD in international trade use this route through each year, and daily about 300 large commercial vessels, including 200 oil tankers from the Europe, Africa to the Asia, Hawaii and the Americas. Serious armed conflict in this area could temporarily close or delay this shipping service, potentially creating losses by the order of USD 14.5 billion dollars per day if ships need to be redirected around the large island of Borneo or elsewhere. This could have a substantial impact on the world economy, and particularly on the economy of China. As economic growth is the top priority goal of each claimant state, the expansive land reclamation and artificial islands building activities in the Spratly reefs and associated military buildup to defend its claims represents a considerable direct economic loss to countries in the region. The tensions that it could create will add further to the instability in the economy and growth of China (Juinion-Meñez \& Gomez, 2016). 


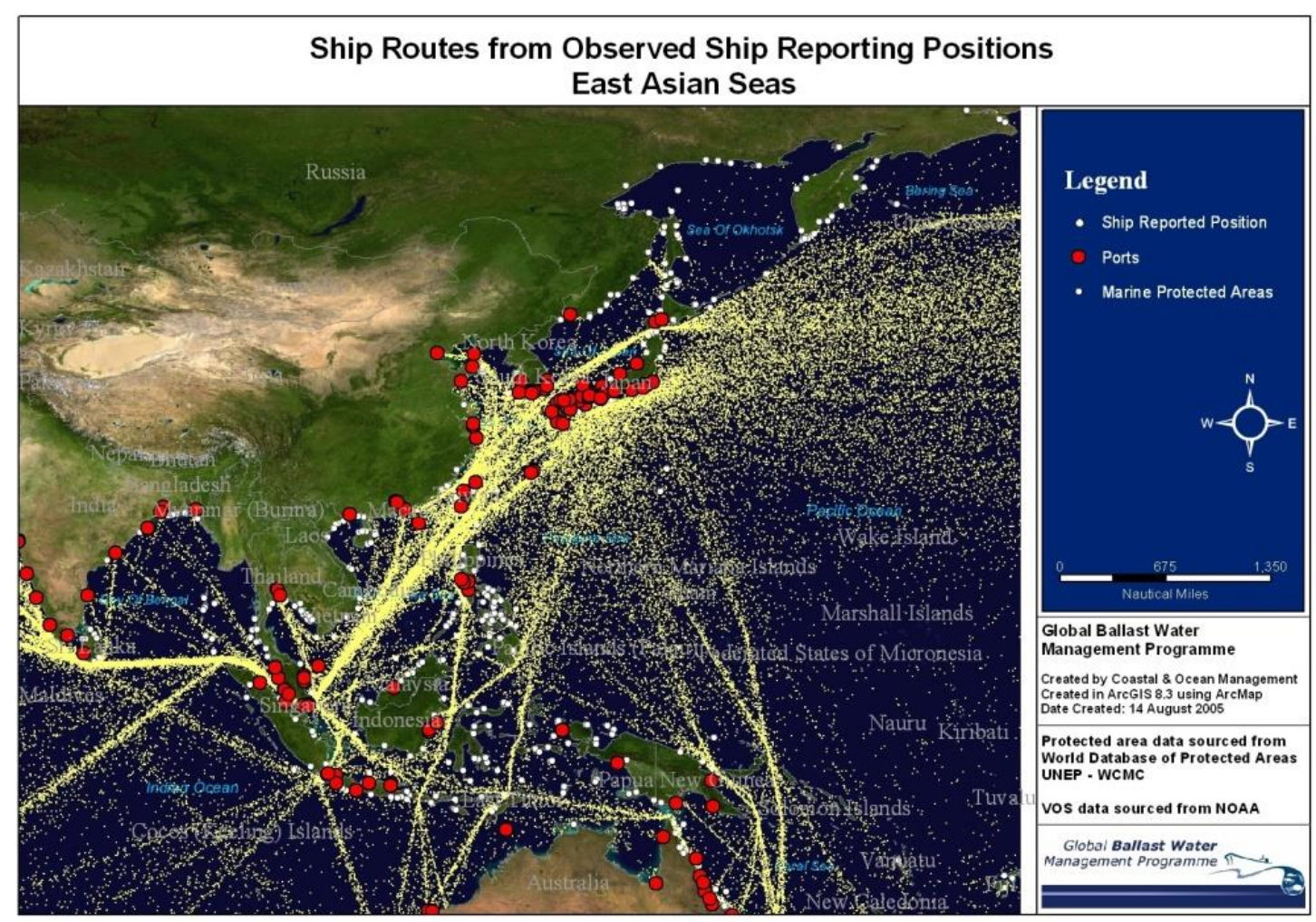

Figure 4. Shipping routes in the SCS and East Asia

(Source: IMO)

From the above-mentioned analysis, one could clearly see that environmental and maritime safety and security in the SCS are under huge threats from unpredictable risks such as: oil spills, ecological risks, navigation incidents, military wastes, etc. These risks will adversely impact the global values of the SCS's vulnerable offshore reef systems, thus establishing PSSAs following the guiding criteria of the MARPOL Convention could be a good idea to protect and preserve the conservative and cultural values of the reef systems, fish habitats and other marine values of the SCS.

A Particularly Sensitive Sea Area (PSSA) is an area that needs special protection through action by IMO because of its significance for recognized ecological or socio-economic or scientific reasons and which may be vulnerable to damage by international maritime activities (MARPOL 72/78). The criteria for the identification of particularly sensitive sea areas and the criteria for the designation of special areas are not mutually exclusive. In many cases a PSSA may be identified within a Special Area and vice versa. The guidelines include criteria to allow areas to be designated a PSSA if they fulfil a number of criteria, including: ecological criteria, such as unique or rare ecosystem, diversity of the ecosystem or vulnerability to degradation by natural events or human activities; social, cultural and economic criteria, such as significance of the area for recreation or tourism; and scientific and educational criteria, such as biological research or historical value (IMO resolution A.982(24)).

The provisions of the United Nations Convention on the Law of the Sea (UNCLOS) are also relevant. The Convention states that when an area is approved to become a PSSA, specific measures can be used to control the maritime activities in that area, such as routeing measures, strict application of MARPOL discharge and equipment requirements for ships, such as oil tankers; and installation of Vessel Traffic Services (VTS) (IMO, 2008).

\section{iii) Other initiatives}

A possible approach to help the slow return of giant clam populations to the SCS has been outlined by Gomez, 2015. It assumes a determined and long-term effort on the part of many countries surrounding the SCS. The example of the Philippines which has been showing a steady increase in populations of the true giant clam, Tridacna gigas, is worth emulating. The process is described in an earlier publication (Gomez\& Mingoa-Licuanan, 2006). It is a multi-decadal effort that is beginning to show encouraging results in the re-establishment of an extirpated species within metropolitan Philippines (Huang et al, 2014 and Larson, 2016). 
It is widely understood that the non-legally binding DOC is insufficient to protect the region's natural resources and political stability. Thus, the moves to conclude a new, more strongly binding Code of Conduct of the Parties in the South China Sea (COC) is very important. In this process, it must be clearly understood that regional stability is indivisibly bound to sustainable fisheries. The exploitation and the protection of critical fish habitats including coral reefs must be a priority. This could be improved by the development of ecologically sustainable tourism and tourism can only grow in the absence of military threats. Thus, developing coastal and marine tourism can help to reduce militarization in the region (Juinion-Meñez \& Gomez, 2016).

In this case, there is a strong need to push for an effective implementation of the item 6 of the DOC which states "Pending a comprehensive and durable settlement of the disputes, the Parties concerned may explore or undertake cooperative activities" for testing political willingness of the claimants. The cooperation in the field, maybe include the topics of: marine environmental protection; marine scientific research; safety of navigation and communication at sea; search and rescue operation; and combating transnational crime, including but not limited to trafficking in illicit drugs, piracy and armed robbery at sea, and illegal traffic in arms" (Huang et al., 2014).

Strengthening the regional cooperation in marine governance to step up peace and stability in the SCS in accordance with the DOC's spirit. Much of the damage to the seven reclaimed reefs may be permanent, but a freeze on ocean filling could go a long way to protect the remainder of the Spratly atolls and islets. Therefore, according to John McManus (2016), options to lessen tensions could include (i) the establishment of a Greater Spratly Islands Peace Park, and (ii) the collaborative management of fisheries, the environment and mineral resources across the entire SCS. Both options require a freeze on sovereignty and maritime claims and activities to reinforce these claims. No matter how it is achieved, regional peace would greatly enhance fisheries stability and economic growth among all claimant nations (Huang et al., 2014).

Practical lessons from The Antarctic Treaty System and other transboundary marine agreements could be shared to the SCS. From an organizational point of view, a Coordinating Body for the SCS (CB-SCS) may be established by the littoral states of the SCS to help achieving both above mentioned options. This Coordinating Body could comprise representatives from the states at Ministerial level with a supportive scientific organ. Its role is to oversee the cooperative management of the marine environment and resources in the SCS. Besides, a Regional Agreement on Sustainable and Responsible Fisheries in the SCS (RASRF-SCS) should be concluded with as objective to preserve the marine living resources for the fishers of all littoral states and their fisheries sectors, to mitigate the illegal fishing activities.

According to McManus, 2016 the regional body which will oversee all resources in the SCS will require regional buy-in and so must include government representation. However, it must also be led by the highest possible quality of science. This is generally not possible when approached solely in terms of national representation. Thus, this body must share the responsibility with an international body of thematic experts. These, in turn should work with independent international organizations which have a responsibility for the SCS resources, such as various UN agencies, regional resource bodies such as SEAFDEC, AFPIC, with the inclusion of experts and focused research efforts tapping from the global pool of scientists. Data sharing and archiving must be mandatory to make optimal use of research expenditures (McManus, 2016).

Thus, in the complicated context of the SCS, the success of any regional cooperation on marine governance must take into account as a minimum condition following elements (McManus, 2016): (i) A freeze on claims; (ii) A freeze on claim-supportive activities; (iii) A reduction in offshore military facilities; (iv) Reinforcement of naval encounter protocols (there are well-developed protocols governing actions associated with encounters at sea and in the air of both military and civilian crafts. These must be recognized as features inherent to the new agreement); (v) Environmental protection must a priority concern, in support of fisheries, tourism, and the broader values of these unique offshore ecosystems; (vi) Environmental impact analysis and mitigation procedures must be held with standards which are consistent regionally, instead of variable among nations. The exploitation of fossil fuels must be regulated in concert with efforts to protect the environment, but also under overseeing to ensure rational benefit distribution, and (vii) Well-defined inspection, arbitration and enforcement procedures. 'Binding' implies enforceable. There must be transparency throughout the offshore SCS, with the unrestricted freedom of visits to any research or development activity by all signatories. There must be clear arbitration procedures for various classes of dispute, and clear actions to be followed in cases of disregard for essential agreement provisions.

\section{Some Final Remarks}

The SCS, which contains global ecologically and environmentally values, is a survival space of its littoral states. The vulnerable and valuable offshore coral reef systems with special features of the SCS play a critical role in maintaining the marine natural assets for blue growth and livelihoods, and in keeping the ecological and biological connectivity not 
only in the offshore reef waters, but also in its remaining parts, and even beyond the SCS.

However, the SCS's offshore coral reef systems were currently under serious environmental threats from recent large-scale land reclamation and artificial island building activities at a number reef features in the Spratly and Paracel Islands. The South China Sea Award states that these activities have caused permanent and severe harm to the offshore reefs environment and violated the legal obligation to preserve and protect fragile ecosystems and the habitat of depleted, threatened or endangered species after.

To address the above mentioned environmental problems, the science diplomacy with new cooperation drivers and approaches to strengthen the SCS regional cooperation regime and implement the blue initiatives and solutions are priority issues in the future. However, the success of implementing proposed initiatives and solutions depend upon some conditions of which the minimum is the political support from the claimants and littoral states around the SCS, as well as of other states beyond it.

Finally, the way to accelerate effective regional transboundary environmental governance requires the respect of international law, in particular UNCLOS and the South China Sea Award by all relevant partners and stakeholders. That how to achieve, together, 'a Blue SCS - a healthy sea, prosperous sea and peaceful sea!'.

\section{Reference}

Award, South China Sea Arbitration, An Arbitral Tribunal Constituted under Annex VII to the 19982 United Nations Convention on the Law of the Sea between the Republic of Philippines and the People's Republic of China, 12 July 2016, PCA Case No 2013-19 [South China Sea Arbitration Award].

Borton, J. (2016). Commentary: Managing the South China Sea Commons through Science Policy. South China Sea Think Tank - Perspectives, 10 (2016). Retrieved from http://scstt.org/perspectives/2016/567.

Borton, J. (2016, August 4). From ruling of the Permanent Arbitration Court to environmental issues. Tien Phong. MacDonwell R. (2011, July 21). A look at the top issues at Asian security meeting. Associated Press. Retrieved from http://www.dailymail.co.uk/wires/ap/article-2830185/A-look-issues-Asian-security-meeting.html.

CBD Secretariat. (2015). Report on regional workshop to facilitate the description of EBSAs in the Sea of East Asia (Xiamen, China, 13 to 18 December 2015). Doc. No. UNEP/CBD/EBSA/WS/2015/3/4.

De Groot et al. (2012). Global estimates of the value of ecosystems and their services in monetary units. Ecosystem Services, 1, 51-60

Declaration on the Conduct Parties in the South China Sea, 2012, July 4. ASEAN. Retrieved from http://asean.org/?static_post=declaration-on-the-conduct-of-parties-in-the-south-china-sea-2.

Gomez, E. D. (2015). Compromising Biodiversity and Economic Productivity in the SCS. Paper presented in National Seminar on The SCS's Environment and Human Behavior, Hai Phong, Viet Nam.

Huang, D. et al. (2014). Extraordinary diversity of reef corals in the South China Sea. J. Marine Biodiversity, 45(2), 157-168.

IMO. (2008). Report on National Workshop on the Particularly Sensitive Sea Areas (PSSA's) held from 5 - 7 November 2008 in Hai Phong, Viet Nam.

IOC Regional Network of Training and Research Centers on Marine Science. IOCWESTPAC. Retrieved from http://iocwestpac.org/capacity-development/49.html.

Juinio-Meñez, M. A., \& Gomez, E. D. (2016, October). Rock-Island-Reef: the high stakes in the South China Sea. Paper presented in the 2nd International Seminar on Envirommental and Maritime Security for a Blue SCS, Hai Phong, Viet Nam, p.2.

Larson, C. (2016). Shell trade pushes giant clams to the brink. Science, 351(6271), 323-324.

Lee, V. R. (2015). South China Sea: Satellite Images Show Pace of China's Subi Reef Reclamation. The Diplomat. Retrieved from http://thediplomat.com/2015/06/south-china-sea-satellite-images-show-pace-of-chinas-subi-reef-reclamation/.

Lee, V. R. (2016). Satellite Imagery Shows Ecocide in the South China Sea. The Diplomat. Retrieved from http://thediplomat.com/2016/01/satellite-images-show-ecocide-in-the-south-china-sea/.

Loftus-Farren, Z. (2015). Building Islands and Burying Reefs in the South China Sea. Earth Island Journal. Retrieved from http://www.earthisland.org/journal/index.php/elist/eListRead/building_islands_and_burying_reefs_in_the_south_c hina_sea/. 
McManus, J. W. (2016). Offshore Coral Reef Damage, Overfishing, and Paths to Peace in the South China Sea. Paper presented in 2nd International Seminar on Envirommental and Maritime Security for a Blue SCS, Hai Phong, Vietnam, p.1.

Mora, C., Caldwell, I. R. Birkeland, C., \& McManus, J. W. (2016). Dredging in the Spratly Islands: gaining land but losing reefs. PLoS Biol, 14(3), e1002497.

Morton, B., \& Blackmore, G. (2001). South China Sea. Marine Pollution Bulletin, 42(12), 1236-1263.

Nguyen Chu Hoi \& Vu Hai Dang. (2015). Building a regional network and management regime of marine protected areas in the South China Sea for sustainable development. Journal of International Wildlife Law \& Policy, 18(2), 128-138.

Nguyen Chu Hoi. (2013). Coastal and Marine Spatial Planning: A National Resource Document for Vietnam. Ha Noi: Publishing House of Agriculture.

Nguyen Chu Hoi. (2016). The Hague Award of the SCS Environment in Lawsuit betwween Philippines and China. Journal of Vietnam S\&T, No.11/2016, 601-64.

Nguyen Chu Hoi. (2016). The marine waters of Hạ Long-Cat Ba limstone islands - Ecologically and Biological Significant Marine Areas (EBSA) at global level. Journal of Vietnam S\&T, 5-2016 (686), 25-28.

Nguyen Chu Hoi. (October 2016). Marine Living Resources Protection in Vietnam through Sustainable Governance of Marine Protected Areas: Shared Lessons and Asian Regional Cooperation Needs. Paper presented in KIOST International Seminar on Ocean Sciences Diplomacy (ISOSD): A Novel Approach to Establishing a Cooperative Regime in the Asian Waters through Ocean Sciences to Promote Regional Peace, Ansan, ROK.

Nguyen Ngoc Truong. (31, August 2016). The rapid exhaustion of the fish in the SCS (translated from Vietnamese: Trung Quốc huỷ hoại Biển Đông không thương tiếc, nghề cá trước nguy cơ sụp đổ). VTC News. Retrieved from http://www.vtc.vn/trung-quoc-huy-hoai-bien-dong-khong-thuong-tiec-nghe-ca-truoc-nguy-co-sup-do-d273742.htm 1.

Nguyen Quang Hung \& Vu Viet Ha. (2015). The marine fishery resources in Viet Nam. Paper presented in National Seminar on The SCS's Environment and Human Behavior, Hai Phong, Viet Nam.

Remarks by Tommy T.B. Koh, President of the Third United Nations Conference on the Law of the Sea, in United Nations - Division for Ocean Affairs and the Law of the Sea, United Nations Convention on the Law of the Sea of 10 December 1982: overview and full text. Retrieved from http://www.un.org/Depts/los/convention_agreements/convention_overview_convention.htm.

Revised Guidelines for the Identification and Designation of Particularly Sensitive Sea Areas, IMO Assembly Resolution A.982(24), IMO OR, 24 ${ }^{\text {th }}$ Session, A 24/ Res 982 (2005).

SIMSEA. Retrieved from http://www.simseaasia pacific.org.

SOA, "Construction Work at Nansha Reefs Will Not Harm Oceanic Ecosystems" (SOA Statement) in June 2015 and a SOA Report in February 2016. Produced in South China Sea Arbitration Award.

The International Convention for the Prevention of Pollution from Ships, as modified by Protocol of 1978, 2 November 1973, 1340 U.N.T.S. 184 [MARPOL 73/78].

United Nations Convention on the Law of the Sea, 10 December 1982, 1833 U.N.T.S. 3 [UNCLOS].

Vo Si Tuan. (2016 October). Regional efforts for biodiversity conservation in the SCS. Paper presented in 2nd International Seminar on Envirommental and Maritime Security for a Blue SCS, Hai Phong, Viet Nam.

Vo Si Tuan. (2014). Fauna of reef corals in the Vienam marine areas. Paper presented in Secondary ational scientific conference proceedings on marine biodiversity and sustainable development, (pp. 315-322). Hanoi, Publishing House of Natural Science and Technology.

Vu Hai Dang. (2015). Establishing a Marine Peace Park in the Spratlys:an option for implementing the DOC in the SCS. In Tran Truong Thuy \& Le Thuy Trang (eds), Power, Law, and Maritime Order in the SCS, 293-315, Lanham: Lexington Books. 


\section{Notes}

' The views expressed are personal opinions of the authors. The authors would like to express their high appreciation for the support from the Diplomatic Academy of Viet Nam for the writing of this paper.

ii The Greater Spratly Islands (GSI) includes Scarborough Reef. These are minimal values, as they are based on available satellite imagery on Google Earth Pro (GEP) as of March 2016, and a few reefs and/or new island expansions may not have been visible. Based on an open US intelligence letter to Sen. John McCain, an additional 404,686 $\mathrm{m}^{2}$ of filling for Subi Reef and Mischief Reef in the GSI, not yet in GEP imagery, has been added for PRC. Known island expansion in the Paracels in late 2015 has not been included due to a lack of area estimates and of imagery on GE. Accuracy is believed to exceed $90 \%$. Giant clamming refers to the digging up of giant clams using propellers on anchored boats pulled laterally.

iii Red colour-exhausted or over-fished, Orange-completely and Green-medium or good.

iv A "enclosed or semi-enclosed sea" is defined by the UNCLOS in its article 122 as "a gulf, basin or sea surrounded by two or more States and connected to another sea or the ocean by a narrow outlet or consisting entirely or primarily of the territorial seas and exclusive economic zones of two or more coastal States".

\section{Copyrights}

Copyright for this article is retained by the author(s), with first publication rights granted to the journal.

This is an open-access article distributed under the terms and conditions of the Creative Commons Attribution License which permits unrestricted use, distribution, and reproduction in any medium, provided the original work is properly cited. 